\title{
Hand stencils and boats in the painted rock art of the karst region of Muna Island, Southeast Sulawesi
}

\author{
Adhi Agus Oktaviana
}

\begin{abstract}
The rock paintings of Muna Island first became the subject of research by Indonesia's National Research Centre of Archaeology in Jakarta, Indonesia, almost 40 years ago. Since then, a large assortment of images has been documented, the majority of which are done using brown pigment. The rock art includes figurative motifs such as anthropomorphs, zoomorphs, sun and boat imagery, sometimes in active scenes like hunting and sailing, as well as non-figurative motifs. In 2005, the first observations of negative hand stencils on Muna Island were made at Gua Pominsa by the Makassar Archaeology Office. In 2015, more negative hand stencils were recorded at two further Muna Island sites (Gua Mentanduno and Gua Kabori) by the Directorate of Cultural Property Preservation and Museums, and in 2016 a new site with parietal art (Gua Lakan Taghu) was discovered. Analysis of the Muna Island boat imagery documents the depiction of five propulsion methods, providing an insight into the navigation technology of Muna Island's Austronesian inhabitants. These new developments in rock art research on Muna Island are described here, expanding the catalogue and contributing to a wider understanding of Island Southeast Asian rock art.
\end{abstract}

Keywords: rock art, hand stencils, boat images, Austronesian Painting Tradition, Muna Island karsts

\section{Introduction}

Visual art is a physical representation of human creativity that has been practised since ancient times, including some of the oldest examples from Island Southeast Asia (ISEA) as revealed in two recent publications in Nature (Aubert et al. 2014, Joordens et al. 2015). Joordens et al. (2015), after revisiting deposits first collected in 1891 by the Dutch scientist, Eugene Dubois, from the open-air site at Trinil in East Java, found zigzag-patterned incisions on a freshwater bivalve that was dated to around 500,000 years ago, thereby attributing their production to Homo erectus. Aubert et al. (2014) dated hand stencils and large animal motifs on the walls and ceilings of caves and rockshelters in the Maros karst system of South Sulawesi using the uraniumthorium (UTh) method, with minimum ages achieved of 40,700 and 36,900 BP, respectively, and younger ages for one stencil of $17,770 \mathrm{BP}$. The youngest of the dated stencils had additional 
pigment applied between the fingers to produce a narrowed or sharpened shape referred to here as narrowed fingers, while the older hand stencils do not show any alterations to the fingers' morphology and are referred to here as normal fingers (Table 6.1).

Table 6.1: Early dates for hand stencils in Island Southeast Asia.

\begin{tabular}{|c|c|c|c|c|}
\hline Site & Region & Hand stencils type & Minimum dates & Reference \\
\hline Leang Timpuseng & $\begin{array}{l}\text { Maros, South } \\
\text { Sulawesi }\end{array}$ & $\begin{array}{l}\text { Hand stencil with normal } \\
\text { fingers }\end{array}$ & $40,700+870 / \leq 840 \mathrm{BP}$ & Aubert et al. 2014 \\
\hline Leang Jarie & $\begin{array}{l}\text { Maros, South } \\
\text { Sulawesi }\end{array}$ & $\begin{array}{l}\text { Hand stencils with normal } \\
\text { fingers }\end{array}$ & $\begin{array}{l}39,670 \pm 320 \mathrm{BP} \text { and } \\
34,980 \pm 410 \mathrm{BP}\end{array}$ & Aubert et al. 2014 \\
\hline Leang Sampeang & $\begin{array}{l}\text { Maros, South } \\
\text { Sulawesi }\end{array}$ & $\begin{array}{l}\text { Hand stencil with normal } \\
\text { fingers }\end{array}$ & $32,600 \pm 760 \mathrm{BP}$ & Aubert et al. 2014 \\
\hline Gua Jing & $\begin{array}{l}\text { Maros, South } \\
\text { Sulawesi }\end{array}$ & $\begin{array}{l}\text { Hand stencils with normal } \\
\text { fingers }\end{array}$ & $\begin{array}{l}30,900+1700 / \leq 1800 \text { and } \\
24,000 \pm 1100 \mathrm{BP}\end{array}$ & Aubert et al. 2014 \\
\hline Leang Barugayya & $\begin{array}{l}\text { Maros, South } \\
\text { Sulawesi }\end{array}$ & $\begin{array}{l}\text { Hand stencils with normal } \\
\text { fingers }\end{array}$ & $\begin{array}{l}29,100+3200 / \leq 3100 \mathrm{BP}, \\
24,000+3100 / \leq 3000 \mathrm{BP} \text {, and } \\
19,700 \pm 1000 \mathrm{BP}\end{array}$ & Aubert et al. 2014 \\
\hline $\begin{array}{l}\text { Leang (Tapuang) } \\
\text { Lompoa }\end{array}$ & $\begin{array}{l}\text { Maros, South } \\
\text { Sulawesi }\end{array}$ & $\begin{array}{l}\text { Hand stencil with normal } \\
\text { fingers; hand stencil with } \\
\text { narrowed fingers }\end{array}$ & $\begin{array}{l}29,300+1200 / \leq 1100 \mathrm{BP} ; \\
17,770 \pm 420 \mathrm{BP} \text {, respectively }\end{array}$ & Aubert et al. 2014 \\
\hline Gua Jeriji Saleh & East Kalimantan & $\begin{array}{l}\text { Hand stencil with normal } \\
\text { fingers }\end{array}$ & $\sim 9900 \mathrm{BP}$ & Plagnes et al. 2003 \\
\hline
\end{tabular}

Note: Two standard dating error ranges are presented for the Maros dates.

Source: Adapted from Oktaviana, Bulbeck et al. (2016).

In Timor Leste, calcite bracketing red pigment in Lene Hara Cave has been dated using the UTh technique to between 29,000 and 24,000 years ago, raising the possibility of equally old painted art in Timor (Aubert et al. 2007). In the Sangkulirang-Mangkalihat karsts of East Kalimantan (Indonesian Borneo), there are hand stencils of probable Pleistocene age: one of these is covered by a stalactite flow dated to around 10,000 years ago (see Table 6.1; Plagnes et al. 2003). These products of human creativity are millennia older than the Neolithic phase of ISEA, which is associated with the southward incursion of early speakers of Malayo-Polynesian (a branch of the Austronesian language family) recorded widely across ISEA in ethnographic times.

Improved technologies for recording and analysing rock art have been more recently implemented in ISEA research to bolster the documentation and understanding of these images. This includes the use of portable 3D scanners with a DStretch plug-in that uses colours to sharply expose subtle contrasts and textures in rock paintings otherwise missed by the observer; an example of this technique was used for the art at Gua Harimau in Sumatra (Oktaviana 2015b). These 3D scanners have also been used for mapping various painted caves in the Maros-Pangkep and Sangkulirang-Mangkalihat karst systems performed under the auspices of the Directorate for Cultural Property Preservation and Museums (Direktorat Cagar Budaya dan Permuseuman).

Most of the recorded rock paintings of Indonesia and Timor Leste are contained within caves (gua), caverns (ceruk) and sea cliffs (Figure 6.1). The most easterly of these have been recorded in West Papua in the karst districts of the Berau Gulf, Kaimana, the Baliem Valley (Arifin and Delanghe 2004), Triton Bay (Gonthier et al. 2013), and Misool (Sulistyarto et al. 2014). Others have been recorded in the Matgugul Kakun karsts on Buru Island (Ririmasse 2007) and at the Tala River in Seleman Bay on Seram (Oktaviana, Lape et al. 2016). Other sites occur on the Kei Islands to the east of Seram (Ballard 1988; Setiawan 1994) and near Kupang in West Timor 
(O'Connor et al. 2015), and in Timor Leste various sites with rock paintings near Tutuala and Baucau (O'Connor 2003), Baguia (O'Connor and Oliveira 2007) and the island of Atauro (Galipaud et al. 2016) .

In the karst regions of Kalimantan, rock art has been recorded since 1995 including sites in the Sangkulirang-Mangkalihat karsts of East Kalimantan (Fage et al. 2010) as well as the sites of Batu Cap (Yondri 1996) and Liang Kaung (Chazine 1999) in West Kalimantan. Recent discoveries include rock art on Sumatra, specifically the Gua Harimau site in the Padang Bindu karsts of South Sumatra (Oktaviana, Setiawan et al. 2016) and Bukit Bulan in the Sarolungan karsts of Jambi (Fauzi et al. 2015). Painted rock art sites on Sulawesi occur in the karsts of Maros-Pangkep (Permana 2005; Aubert et al. 2014), Bone (Oktaviana, Bulbeck et al. 2016), Morowali and Matarombeo (Fage 2015), as well as Muna Island, which is the focus of this contribution.

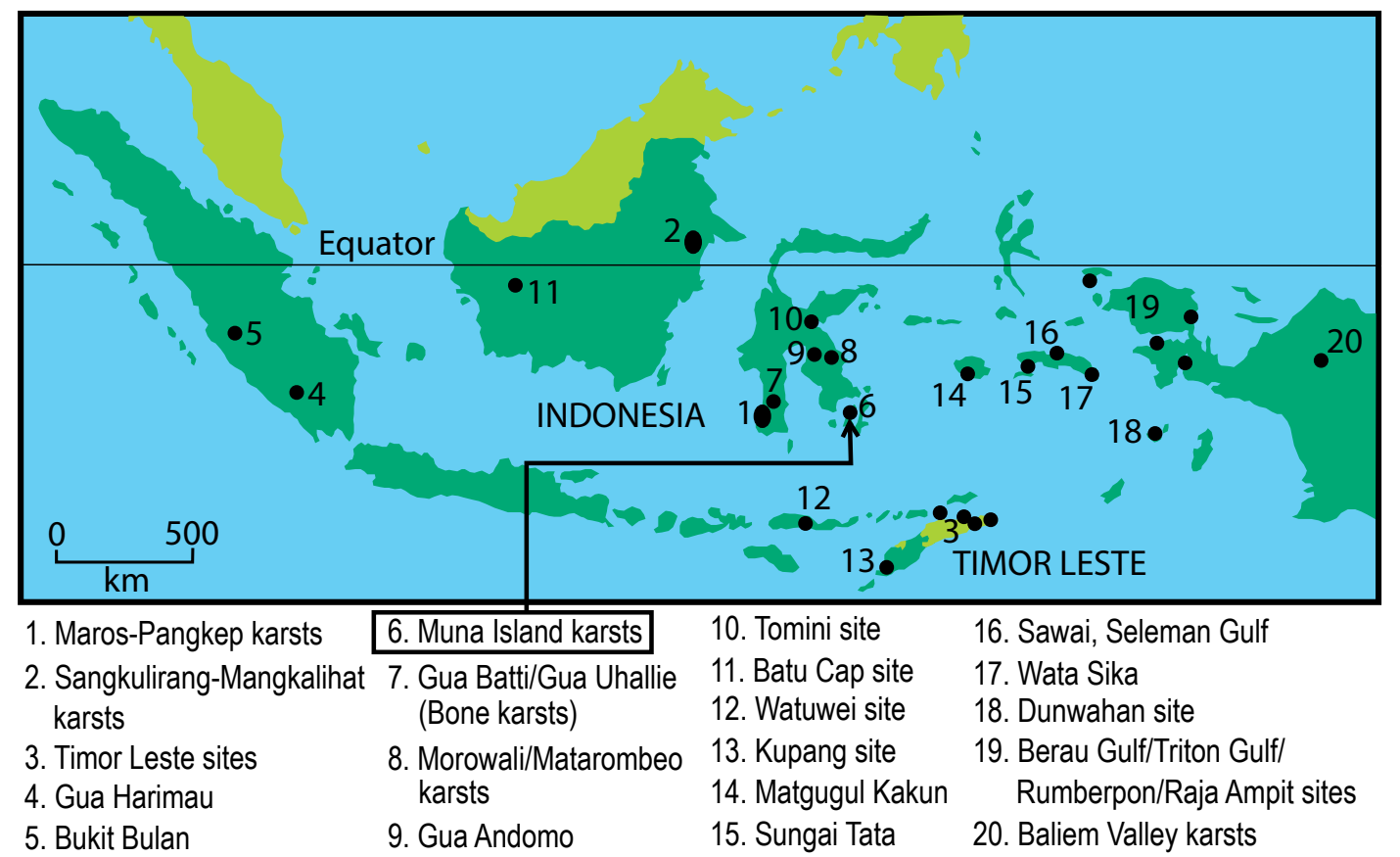

Figure 6.1: The distribution of painted rock art in Indonesia and Timor Leste.

Source: Adapted from Oktaviana (2016).

\section{Fieldwork area}

The general fieldwork area for this study is the Muna Island karsts (Figure 6.1), which are part of the Muna District in Southeast Sulawesi Province. The rock art contained within this region was first documented by Indonesia's National Research Centre for Archaeology in 1977, with further studies in 1984 and 1986 (Kosasih 1985, 1989, 1995). The 10 sites of Gua Metanduno, Gua Kabori, Gua Wa Bose, Gua Toko, Gua La Kolumbu, Ceruk Ida Malangi, Ceruk Lasabo A, Ceruk Lasabo B, Ceruk La Nsafora and Ceruk Tangga Ara were recorded for a variety of motifs including anthropomorphs, zoomorphs, sun and boat motifs, and warfare and hunting weapons that were possibly made from metal. These motifs were painted on cave walls and ceilings and on cavern walls. Most of the images were produced using brown pigments, though some are black 
and a small number are red. ${ }^{1}$ Kosasih (1995) wrote that the diversity of these paintings reflects the lifestyle and daily realities of the past communities that produced them, characterised by dynamic activities such as hunting, combat and warfare.

One main focus of this contribution is the recent discovery of hand stencils from the Liang Kabori village, Lohia Subdistrict, Muna District. Rock art research has been conducted for around 40 years across the island, yet it was not until 2005 that reports surfaced of negative hand stencils, which are a common motif throughout the Sulawesi karst systems (for example, those at MarosPangkep, Bone and Lake Towuti in South Sulawesi, and Matarombeo in Southeast Sulawesi) (Oktaviana, Bulbeck et al. 2016). Archaeologists from the Makassar Archaeology Office recorded hand stencils at Gua Pominsa, with further hand stencils later found at Gua Metanduno and Gua Kabori where their presence had been overlooked during previous studies of these sites' rock paintings (e.g. Aksa (1991) for Gua Kabori; Kosasih (1995) for Gua Metanduno and Gua Kabori; and Alamsyah (2014) for Gua Metanduno).

\section{Methods}

Direct observations of the art were undertaken in 2015 by the Directorate of Cultural Property Preservation and Museums, the Ministry of Education and Culture (during its preparation of the Muna Island chapter for an illustrated edition of the rock art of Indonesia), the author as a representative of the National Research Centre of Archaeology and Pindi Setiawan from the Bandung Institute of Technology. These observations documented the parietal art of various caves and caverns, including Gua Metanduno, Gua Kabori, Ceruk Ida Malangi, Gua Sugi Patani, Ceruk La Podo, Gua Pominsa and Ceruk Lakan Taghu (Figure 6.2). A review of the literature was done to contextualise these observations with those from earlier texts relating to the prehistoric art in the Muna Island karsts, including Kosasih $(1987,1989,1995)$ and BCPBM (2015).

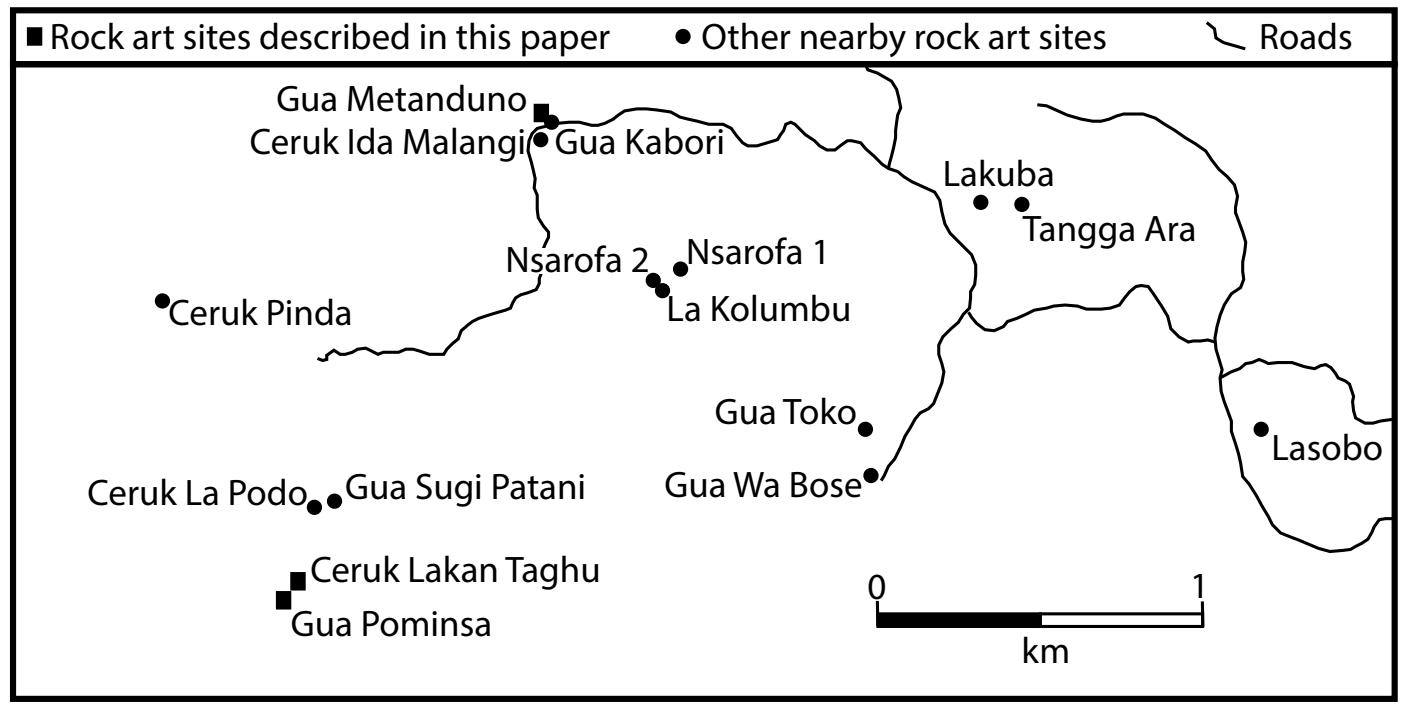

Figure 6.2: Rock art sites in the study area.

Source: Adapted from Oktaviana (2016).

1 See Marschall and Wäfler (2012) for site maps, photographs and sketches of the rock art from Gua Metanduno, Gua Kabori, Gua Wa Bose, Gua Toko, Gua La Kolumbu and Ceruk Lasabo. 
Several phases of work were implemented to systematically record and analyse the rock art at all of the relevant sites (Oktaviana, Bulbeck et al. 2016; Oktaviana, Setiawan et al. 2016). The first step was to describe the geographic locality of the site and the positioning of the art at the site. Observations were then made to identify if there was any apparent directionality or implicit movement of the images across the panel(s) and whether it went to the left, right or swivelled around. The rock paintings were described and their dimensions, colour, type, creation technique, position in the panels and condition were documented (Maynard 1977; Arifin 1992). Once the type, location and directionality of the imagery across the site were determined, photographs were taken of each panel that captured the context of the depictions in their panels. A handheld digital camera with LED lighting was used to record the art, including use of an International Federation of Rock Art Organizations (IFRAO) standard scale (where possible). The panels and their motif compositions were sketched in the field in an effort to minimise error from parallax in the photographs. The next phase involved downloading the files from the camera to a laptop computer. Metadata for the photographs was created during fieldwork for the photographic records.

The photographs of the Muna Island karst rock paintings were processed with the ImageJ application and a decorrelation stretch (DStretch) plug-in. This plug-in was used to clarify motifs (including false-colour enhancement) as they are often faded or obscured by dirt, or by other superimposed images (Harman 2008; Le Quellec et al. 2015; Oktaviana 2015b). Finally, analysis was performed on the hand stencils and boats from the Gua Metanduno, Gua Pominsa, Gua Kabori and Ceruk Lakan Taghu sites.

\section{Gua Pominsa}

In 2005, the Makassar Archaeology Office undertook the first study of Gua Pominsa and reported two hand stencils at the site. This finding was queried by the Indonesian rock art community on the basis that there were no prior records of hand stencils found on Muna Island during previous years of archaeological inspection. In 2014, BCPBM sent a team to Gua Pominsa who confirmed that the hand stencils were, in fact, present. Additional hand stencils at this site were recorded by the Directorate for Cultural Property Preservation and Museums in 2015.

The geographic coordinates of Gua Pominsa are $4^{\circ} 54^{\prime} 38.0^{\prime \prime} \mathrm{S} 122^{\circ} 40^{\prime} 13.9^{\prime \prime} \mathrm{E}$ and the altitude is 277 metres above sea level ( $\mathrm{m}$ asl). The site is reached by driving along a $4 \mathrm{WD}$ track for about 300 $\mathrm{m}$, then walking for about $1 \mathrm{~km}$ through hilly terrain on a maintained trail (see Figure 6.2 for the location of the site in the survey area). The walking trail is bordered by stone walls marking local farmers' garden plots. Access to the site is via a $6 \mathrm{~m}$ high wooden footbridge. Gua Pominsa has two separate galleries, each involving multiple panels. The first gallery is encountered at the exit of the footbridge when entering the site, and the other is to the east in a more external position.

This exterior gallery contains hand stencils (Figure 6.3), as well as human, animal, flying and geometric figures. The interior gallery (Figures 6.4-6.6) has various human figures (often holding weapons) in an upright stance, riding horseback or in a boat; the panel also contains geometric figures. The figurative designs are generally positioned between $30 \mathrm{~cm}$ and $200 \mathrm{~cm}$ above the cave floor and were produced mostly through the direct application of brown pigment to the walls of the cave. There are also some black drawings whose pigment was derived from charcoal. The hand stencils were created by spraying pigment onto the wall where a hand was placed. One of the human figures is covered by calcite (Figure 6.7), allowing the potential for future UTh dating at the site (Oktaviana 2015a). 


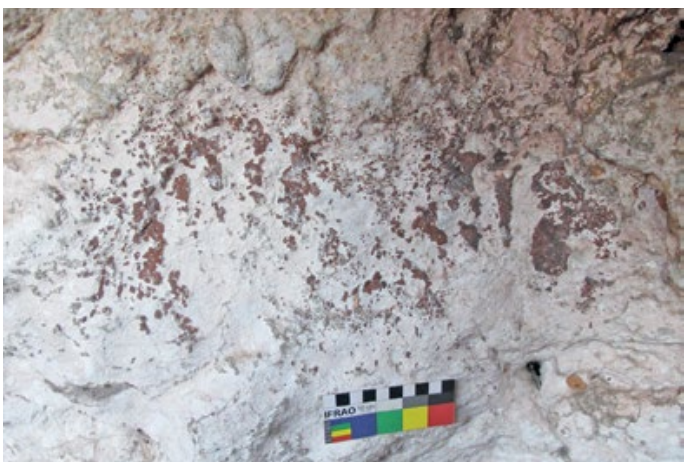

Figure 6.3: Pair of negative hand stencils at Gua Pominsa.

Source: Oktaviana (2016).

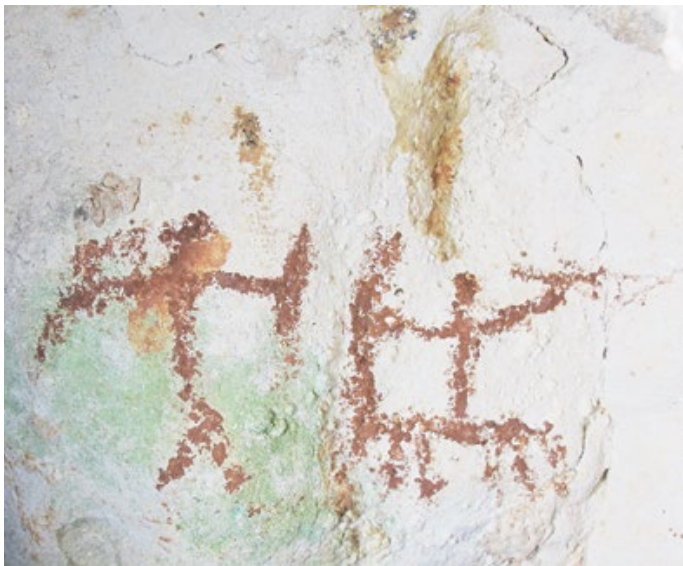

Figure 6.5: Human figures bearing weapons including one riding horseback at Gua Pominsa. Source: Oktaviana (2016).

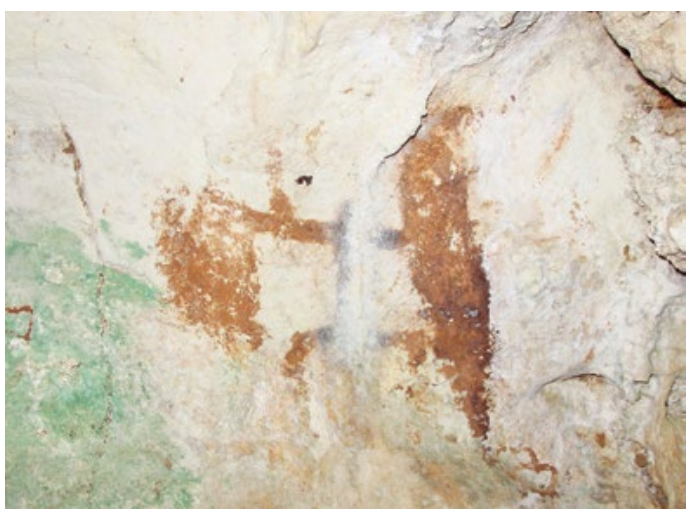

Figure 6.7: Human figure with calcite coating at Gua Pominsa.

Source: 0ktaviana (2016).

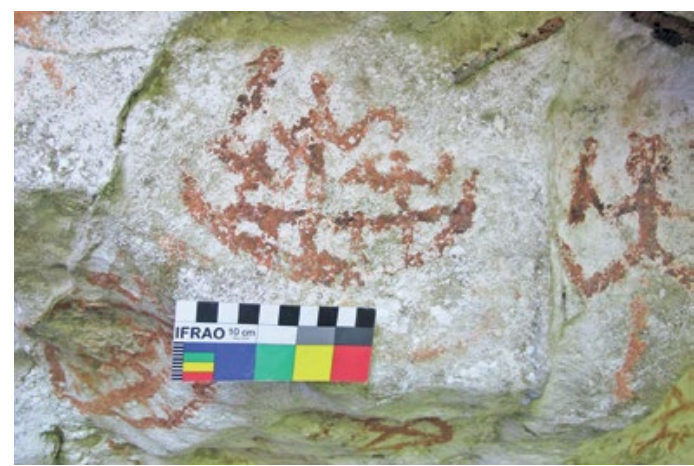

Figure 6.4: Human figures bearing weapons including three on a boat at Gua Pominsa. Source: Oktaviana (2016).

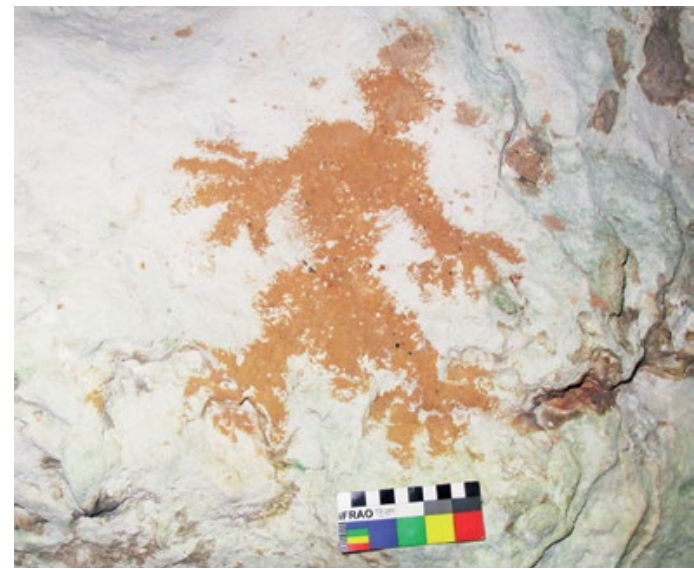

Figure 6.6: Human figure with digits outstretched at Gua Pominsa. Source: Oktaviana (2016). 


\section{Gua Metanduno}

Gua Metanduno is a prime tourist destination on Muna Island and is easily reached along the

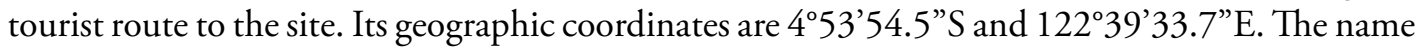
of the site in the Muna language means to clash horns (bovids implied). The cave is shaped like a dome with a northwesterly orientation, and measures $21 \mathrm{~m}$ across its mouth, $23 \mathrm{~m}$ from the entrance to the rear, $25 \mathrm{~m}$ at its greatest width and $8 \mathrm{~m}$ high (Figure 6.8, centre). The interior cave is full of collapsed rubble from the walls and roof, and in various places stalactites and stalagmites are actively forming. A rudimentary staircase has been built at the front of the cave to create an easy access point for visitors.

The rock paintings are generally still visible, notwithstanding some vandalism on the left wall and inside the cave. Some of the paintings are covered with green lichen and some of the images are peeling away from the wall. Most of the paintings are in the cave's well-lit zone. Kosasih (1985) originally recorded 316 paintings at this site. The painted motifs include a wide variety of human figures, horses, deer, pigs, dogs, chickens, snakes, centipedes, boats, sun figures, hand stencils, and unidentifiable motifs (Figure 6.8). The large corpus of work was created mainly using brown and red ochre, along with charcoal for the black figures. The painting techniques used at the site consisted of applying pigment directly to the walls producing solid stick figures, outlines and solid infill depictions of humans and animals, except for the hand stencils, which were made with sprayed pigment. One of the hand stencils can be found on the inside of the cave and another five at the right of the entrance, all of which were found later during the 2015 survey at the site.

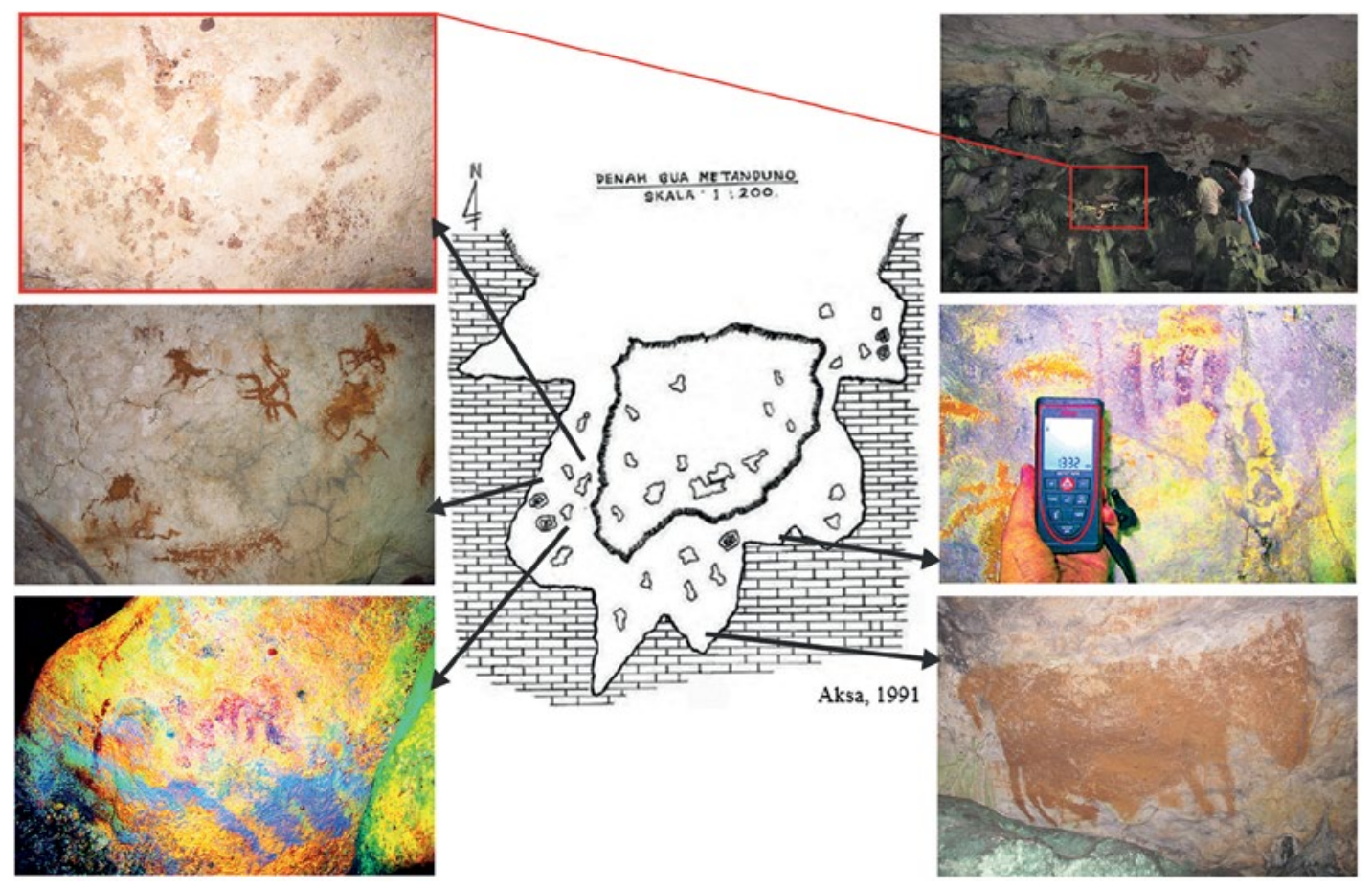

Figure 6.8: Mosaic of Gua Metanduno rock art.

Clockwise from top left: hand stencils; interior site plan with rubble and location rock art; site inspection with location of hand stencil in red; example of false-colour image enhancing; possible bullock figure; false-colour image enhancing of hand stencil within cave's interior; Figure 6.11 panel.

Source: Oktaviana (2016). 
The greatest variety of the Gua Metanduno rock art is positioned to the left of the cave mouth, with rock art extending to the interior of the cave as well as to the right of the cave mouth. The left wall contains human figures, mounted warriors, flying humans, boats with passengers, sun figures and geometric designs; all of them in miniature and located between $1 \mathrm{~m}$ and $2 \mathrm{~m}$ above the floor. The cave interior has mostly miniature designs dominated by a variety of human figures, deer, horses, boats with passengers (some of the boats with covered decking), sun symbols, a hand stencil and unidentified motifs. The largest figure resembles a bullock. It is facing to the right and its back legs overlie a portion of an adjacent boat motif (Figures 6.9 and 6.10). The main motifs on the right and left sides of the cave are boats with more than one passenger. The hand stencil within the cave's interior has just three fingers stretched out and is located at $1.3 \mathrm{~m}$ above the cave floor near an anthropomorphic figure.

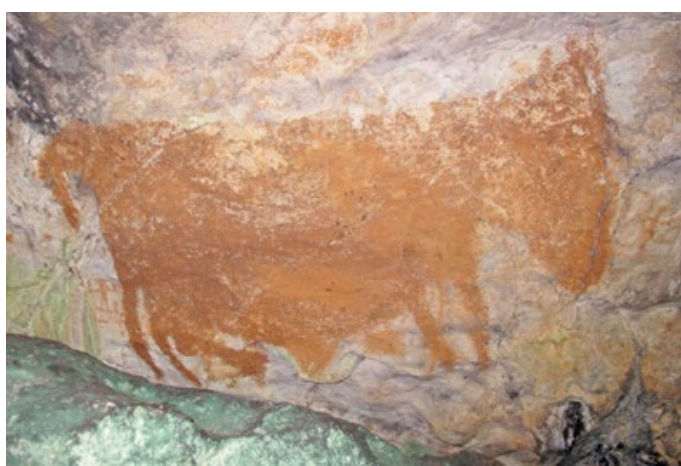

Figure 6.9: Male zoomorph within Gua Metanduno interior panel.

Source: Adhi Agus Oktaviana.

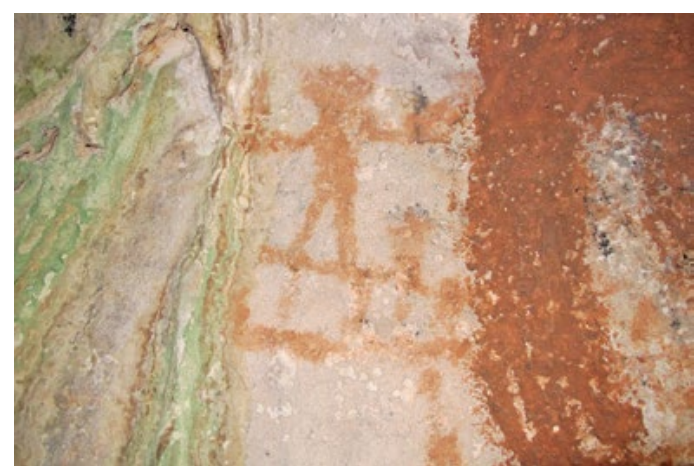

Figure 6.10: Detail of human figure standing on 'boat', superimposed by back legs of male zoomorph, Gua Metanduno cave.

Source: Adhi Agus Oktaviana.

The right-hand side of the cave is painted with many scenes of horse riders and their dogs hunting deer and pig. Several of the horses have large dimensions but their riders are depicted as disproportionately small. There is also a painting of a hunter spearing a deer. Horses are more dominant on this wall compared with the interior or left wall of the cave. This wall also has a stencil of a hand with sharpened or narrowed fingers underneath (and older than) a painting of a chicken (Figure 6.11, top right). There is also a hand stencil with normal fingers near the head of the chicken (Figure 6.11, top left), covered in part by coralloid speleothems, which could be used for dating (Aubert et al. 2014). Nearby are three other hand stencils. Two of these hand stencils were identified on a boulder turned toward the outside of the cave (Figure 6.8, top left), while the third was found in a section of the ceiling somewhat hidden by obtruding rocks (Oktaviana 2015a).

The Gua Metanduno human figures are depicted in a multitude of activities and dynamic actions, including mounted and unmounted hunters, humans in combat, humans with hands on their waist, flying humans, and apparently unfinished paintings. The cave paintings overall are dominated by horses, which probably arrived in Muna within the last 500 years or so (see Discussion). The rock art often features boats with passengers, perhaps suggesting interisland voyaging for trade and/or combat. 


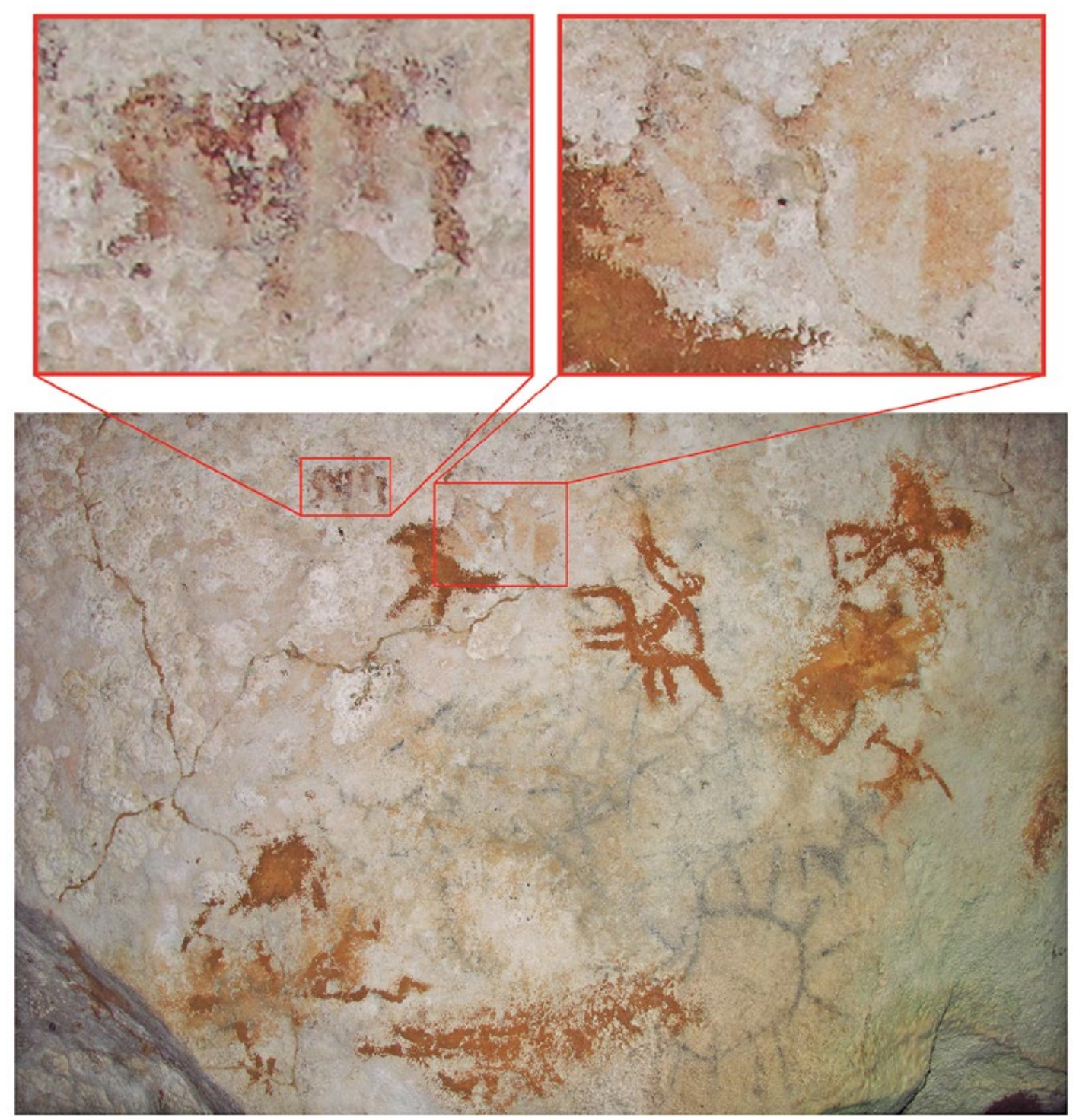

Figure 6.11: Gua Metanduno panel.

Top left: ochre hand stencil with normal fingers near chicken head; top right: hand stencil with sharpened fingers beneath chicken; bottom: human figures (one riding a horse) and faunal figures, charcoal drawings of a sun motif (superimposed by a boat motif) and human figure.

Source: Oktaviana (2016).

The belated discovery of hand stencils at Gua Metanduno supports the need for further inspections of known cave art sites on Muna Island. While most of the hand stencils at this site have normal digits, one of them had the fingers modified to appear sharpened or narrowed. This stencil possibly reflects a tradition that originated in the Maros-Pangkep karsts before spreading to the Southeast Sulawesi including Muna Island (Oktaviana, Bulbeck et al. 2016). At least one stencil underlies the red-brown pigment art and its faded condition suggests greater antiquity (Figure 6.11). 


\section{Gua Kabori}

Gua Kabori is located $25 \mathrm{~m}$ southeast from the Gua Metanduno site. The cave is dome-shaped with ledges along the wall. Its mouth faces west, and there is an ongoing process of stalactite and stalagmite formation. The term kabori translates to a cave with writing (or drawings). As originally recorded by Kosasih (1985, 1995), the cave paintings include numerous anthropomorphs and zoomorphs as well as the sun motif. The scenes of human activity include hunting scenes, horse riders, passengers on boats and flying humans. The animal figures include horse, deer, dog, crocodile, monitor lizard and centipede. There is also a poorly preserved hand stencil at around $3 \mathrm{~m}$ height on the right side of the cave wall, with three fingers remaining (Figure 6.12).

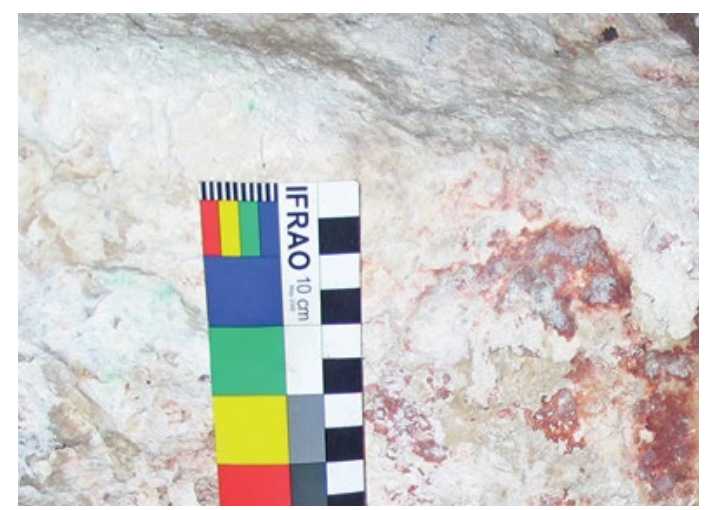

Figure 6.12: Three-fingered hand stencil at right wall, Gua Kabori.

Source: Adhi Agus Oktaviana.

\section{A new site: Ceruk Lakan Taghu}

Ceruk Lakan Taghu (Figure 6.13) is located in the same part of the Muna karsts as Ceruk Sugi Patani and Gua Pominsa (Figure 6.2), at $4^{\circ} 54^{\prime} 35.9$ "S $122^{\circ} 40^{\prime} 12.6$ "E. This rockshelter was discovered by the author in 2015 after faded paintings were seen on the Lakan Taghu hill during the survey trip for Gua Pominsa rock art.
The rockshelter has two terraces that are linked by a passage that is $1 \mathrm{~m}$ high and $40 \mathrm{~cm}$ in breadth. When first approaching the site, it is possible to see multiple rock paintings including boats with their sail unfurled, two human figures, and a human figure gazing out. Underneath the human figures, there are geometric motifs and an image resembling a comb or faunal emblem. The external surface of the cave on a lower wall has a human figure that is oriented to the right.

Access to the left-side terrace involves climbing over a steep rock pile. The outer part has a standing human figure with one arm pushed away from the waist and to the left, and two bandy legs. The interior has at least 27 figures on the wall (Figure 6.13, lower right), including humans riding horses, figures in an upright pose (one with his arm extended from his waist to the right, others with extended arms and hands stretched up with fingers joined together facing out) and various triangular designs facing out (though it could be that these are unfinished parts of other figures). Quadruped mammals are also present. Within the interior section of this terrace that connects to the right-side terrace of the site is a boulder that carries the design of a flying human with the head directed downwards, and adjacent to it is a horse rider facing right. Another boulder has two boats with sail unfurled. The boat on the right is shown as though being held by a figure in upright pose. All of these figures are in brown pigment and appear to have been created by using fingers to apply the pigment. Unfortunately, this terrace has been vandalised by people writing their name and the year, along with some recent human figures drawn in charcoal. 


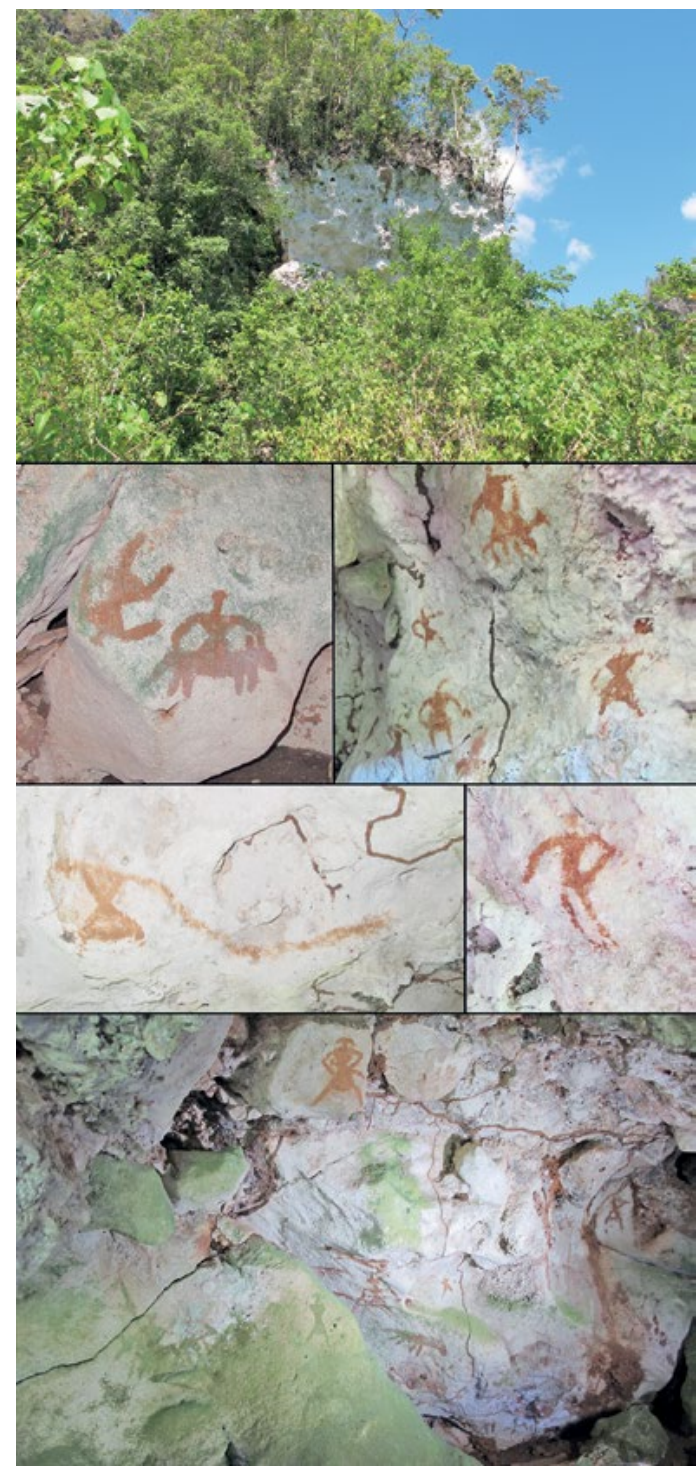

Figure 6.13: Ceruk Lakan Taghu (top) and some of its rock paintings (below).

Source: Oktaviana (2016).

The right-side terrace is a $2 \mathrm{~m}$ high corridor that penetrates the karst at this point. Various paintings can be found here, including an external ceiling panel with brown fingerpainted figures. This panel features two figures in upright pose who are disproportionately large compared with the animals below them in the panel. There is a beast with a disproportionately large head, and beneath its right legs, a human figure with only half of a body and an elongated right arm. This panel contains about 14 figures, mainly human, painted with a brown pigment. The interior panel has a human figure lacking its head and with an unnaturally long left arm (Figure 6.13, upper right). There are also four human figures with headbands and their arms extended from their waist holding weapons. There are several more human figures either upright or riding horses as well as animal images. Unfortunately, the paintings here are covered with lichen, owing to the orientation of the walls facing the cave opening and, therefore, the external environment (Oktaviana 2015a).

\section{Discussion}

The animals represented in the Muna panels are potentially instructive in terms of the age of the paintings. There is indirect evidence for the introduction of the chicken to ISEA in the Neolithic when pottery and other domestic animals such as dogs and pigs were also introduced (Bellwood 2017), so scenes containing these animals would have been painted sometime in the last 3500 years. In Indonesia, as in other parts of Southeast Asia, cock fighting has been argued to have a ritual or symbolic function, being closely associated with male blood-letting, and having replaced various forms of traditional warfare and headhunting (Maxwell 1990:150), so it is possible that the chickens in the painted panels represent more than just subsistence scenes. However, a shallow time depth for many of the chicken and other brown and red pigment motifs is supported by the prominence of horses and horses and riders in the panels. Although there is no archaeological evidence for the date of introduction of the horse into Sulawesi, or for that matter into other islands in Indonesia, it is likely to have been in the late historic period. By 1650 BP, one king in southeastern Sumatra had imported horses from India (Hall 1992:194), another king in Borneo had performed horse sacrifices, but the earliest record for horses in Southeast Sulawesi (or anywhere in Sulawesi) dates to the 4th century BP (Whitten et al. 1987:76). Accordingly, the panels in Muna showing horses being used for hunting and combat are unlikely to be older than c. 500 years ago. 
The presence and implications of the boat images and hand stencils on Muna Island are important for discussion, despite being less common than the zoomorphic images such as deer, horses and dogs. Setiawan (2010) proposed that the boat imagery is associated with the influence of Austronesian (Malayo-Polynesian) speakers. Hand stencils were clearly present prior to the immigration of Austronesian speakers who nonetheless may have continued the tradition.

There has been extensive research done on hand stencils across Indonesia from the karsts of East Kalimantan to West Papua. Special designs have been observed in several regions, such as the points and lines painted inside more than 30 of the 40-plus normal-fingered, red hand stencils in one cluster of hills in the Sangkulirang-Mangkalihat karsts (Fage et al. 2010; Setiawan 2010). A variety of hand stencils largely restricted to the karst regions of southwest and northeast South Sulawesi has narrowed fingers made by adding pigment to fill in space between fingers or, sometimes, from two superimposed hands (Oktaviana, Bulbeck et al. 2016). The southern Misool region (Raja Ampat) also has an unusual design feature where hand stencil variations are produced with two hands clasped together (Chazine 2011; Sulistyarto et al. 2014).

The Leang-Leang karsts of Maros have the greatest number of hand stencils in a single Sulawesi location, and have some of the oldest associated dates of between 40,000 and 18,000 years ago (Table 6.1). One stencil dating to 18,000 years ago at Leang-Leang has narrowed fingers, which is a variant that has also been recorded in the Bone karsts, the Lake Towuti karsts and the Matarombeo karsts near Kendari, and now at Gua Metanduno (Oktaviana, Bulbeck et al. 2016). The documentation of hand stencils at Gua Kabori, Gua Pominsa and Gua Metanduno carries considerable significance because it demonstrates that the tradition of creating stencils did, in fact, include Muna Island. The stencils at these three sites are relatively plain, lacking the infill of geometric designs noted for certain stencils from Kalimantan sites, and the majority of them have normal fingers. All of them are faded, many of them are covered by flowstone, and the narrowfingered stencil at Gua Metanduno is overlain by a brown painting of a chicken. These last three observations suggest that at least some of the Muna Island hand stencils are older than the Muna Island zoomorphs.

The hand stencils found in the Muna karsts suggest the possibility of a local variant of preAustronesian culture. Dates are needed to confirm this claim, and the coralloid speleothems that cover one of the Gua Metanduno stencils may prove suitable for dating.

Table 6.2: Recorded prau motifs in the Muna karsts.

\begin{tabular}{|l|r|r|}
\hline Site & Number of prau motifs & Source \\
\hline Gua Mentanduno & 17 & Kosasih 1995 \\
& 13 & BCPBM 2015 \\
\hline Gua Kabori & 16 & Kosasih 1995 \\
& 9 & BCPBM 2015 \\
\hline Gua Pominsa & 14 & BCPBM 2015 \\
\hline La Kolumba & 2 & Kosasih 1995 \\
\hline Lasobo A & 2 & Kosasih 1995 \\
\hline Lakuba & 1 & BCPBM 2015 \\
\hline Ceruk Lakan Taghu & 2 & Oktaviana 2016 \\
\hline
\end{tabular}

Source: 0ktaviana (2016).

The prau (boat) images from the Ceruk Lakan Taghu site are a recurring maritime motif in the Muna karsts with a minimum of 43 recorded from seven sites (Table 6.2). Boat images are widespread across ISEA including the Kain Hitam 'Painted Cave' at the Niah Caves in Sarawak (Szabó et al. 2009), Gua Mardua in the Sangkulirang karsts of East Kalimantan (Setiawan 2004), 
Gua Sumpangbita and Gua Bulu Sipong in South Sulawesi (Kosasih 1995; Suprapta 1996), at a number of caves in Tutuala in Timor Leste (Lape et al. 2007), at Dunwahan in the Kei Islands (Ballard 1988) and the Berau Gulf in West Papua (Arifin and Delanghe 2004).

Five methods for propelling the boats are depicted in the Muna karst sites (Oktaviana 2009, 2012; see Figure 6.14): (1) paddling by a single person who is seated and holding oars, seen at Gua Pominsa and Gua Mentanduno; (2) paddling by multiple oarsmen, at Gua Pominsa and Gua Mentanduno; (3) single-masted sails, at Gua Pominsa and Ceruk Lakan Taghu; (4) sailing by a person with a combined sail and banner, at Gua Kabori; and (5) sailing by a person with a two-masted sail, at Gua Kabori. These images have not been dated in either relative or absolute terms, and so it is not possible to determine whether they reflect a progression of increasing technological complexity or whether they document the variety of watercraft that would have been available to Muna's Austronesian-speaking inhabitants, at least in historic times. Nonetheless, they indicate that human inventiveness was well-developed during earlier times and that the region's traditional knowledge included mastery of sailing technology, thus adding greatly to the cultural heritage at Muna Island.

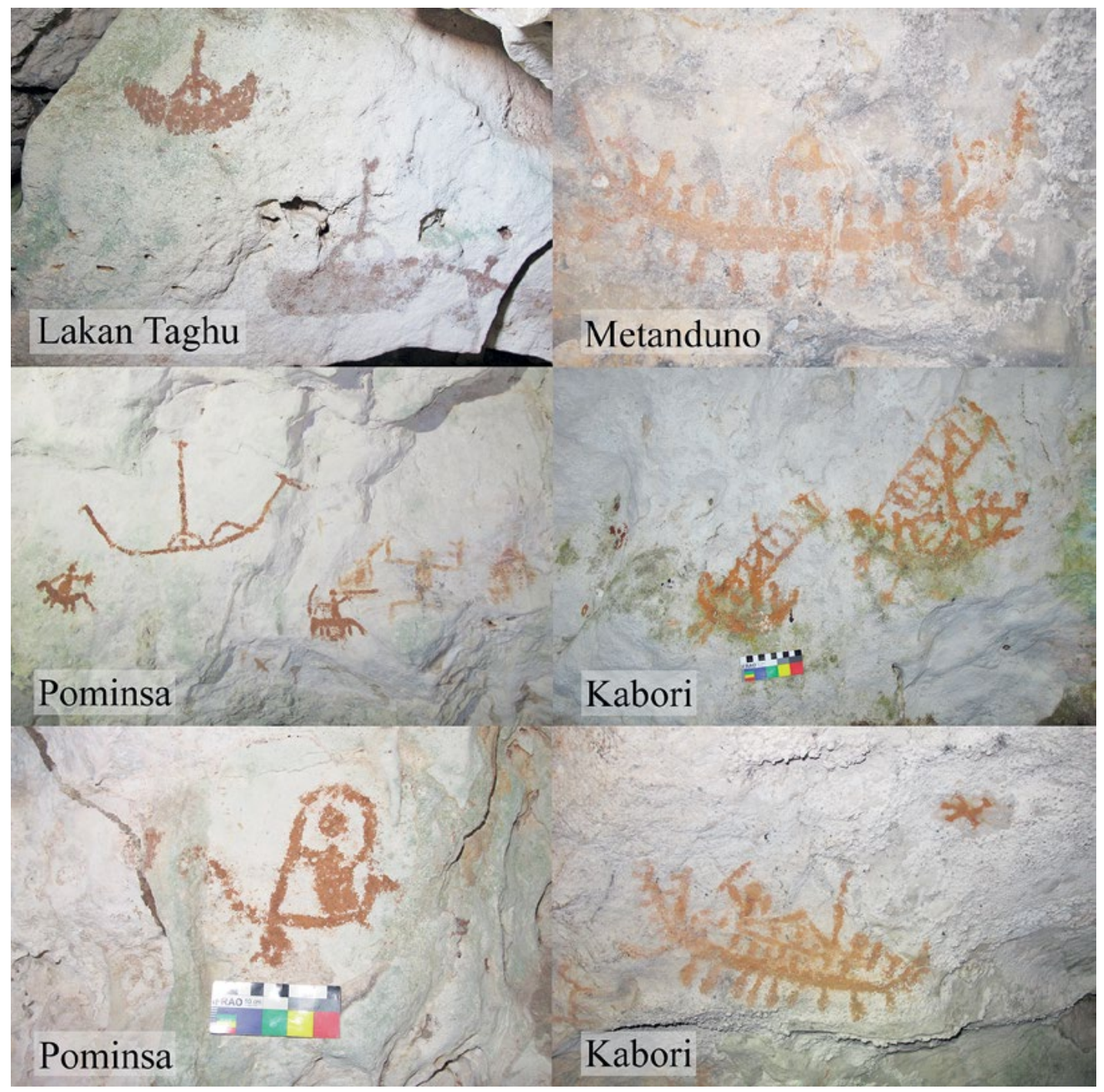

Figure 6.14: Examples of prau motifs from sites in the Muna karsts.

Source: Oktaviana (2016). 


\section{Conclusions}

The archaeological potential of the Muna Island karsts has been investigated for 40 years, leading to the documentation of figurative paintings of hunting scenes, sailing and other activities as well as non-figurative paintings. The absolute chronology of the Muna art motifs is not known, but the observation of superimpositions at Gua Mentanduno suggests a relative chronology that would be consistent with the following order for the motifs' inceptions: (1) hand stencils, (2) sun symbols, (3) boat images and (4) zoomorphs. Human figures occur in compositions with introduced domestic animals such as horses, dogs and deer; in hunting scenes, in boats, individually and in groups. The paintings of birds that appear to represent chickens probably reflect a painting event in the last 3500 years. The same is likely to apply to the bovids, which may represent cattle or buffalo, both introduced after this time (Bellwood 2017). The paintings that include horses may be amongst the more recent and probably date to the historic period.

Comparing the distribution of the painted caves and caverns with the distribution of the karst belt within Muna Island, we can see that archaeological survey should continue so as to appreciate the full potential of Muna's parietal art. The recent discovery in 2016 of paintings on a sea cliff near the port of Raha by the Directorate for Cultural Property Preservation and Museums exemplifies the potential for finding more art on the island. In addition, as a first step towards ascertaining an absolute chronology for the Muna parietal art, UTh dates could be obtained from the calcite covering a Gua Pominsa anthropomorph (Figure 6.7) and the coralloid speleothems formed above one of the Gua Mentanduno hand stencils (Figure 6.11). Similarly, Accelerator Mass Spectrometry (AMS) dating on the charcoal images would provide direct dates on one component of the Muna Island rock art, even if the black images may be generally younger than the paintings in red or brown pigment. The results would assist in placing the Muna rock paintings in a temporal context with rock art recorded elsewhere in Indonesia and add to the understanding on possible migration routes of the people who introduced rock art across Indonesia. It is also vital that rock art conservation is paid more attention by stakeholders who have authority over the Muna Island karst sites. The BCPBM and the local tourism office should implement ways to monitor activity at the sites and deter acts of vandalism by tourists and other visitors.

\section{Acknowledgements}

The author gratefully acknowledges the valuable comments of two anonymous referees.

\section{Author biography}

Adhi Agus Oktaviana The National Research Centre of Archaeology, Research and Development Agency, Ministry of Education and Culture, Jakarta, Indonesia

\section{References}

Aksa, M.L. 1991. Lukisan Dinding Gua Metanduno dan Gua Kabori di Pulau Muna, Sulawesi Tenggara (Suatu Analisa Arkeologi). Unpublished Bachelor of Arts (Drs) thesis, Jurusan Sejarah dan Arkeologi, Hasanuddin University, Ujung Pandang [Makassar].

Alamsyah, N. 2014. Bentuk dan Letak Motif Kuda pada Gua Metanduno, Pulau Muna Sulawesi Tenggara. Unpublished Bachelor of Arts (Drs) thesis, Program Studi Arkeologi, University of Indonesia, Jakarta. 
Arifin, K. 1992. Lukisan Batu Karang di Indonesia: Suatu Evaluasi Hasil Penelitian. Depok: Lembaga Penelitian-Universitas Indonesia.

Arifin, K. and P. Delanghe. 2004. Rock Art in West Papua. Paris: UNESCO Publishing.

Aubert, M., A. Brumm, M. Ramli, T. Sutikna, E.W. Saptomo, B. Hakim, M.J. Morwood, G.D. van den Bergh, L. Kinsley and A. Dosseto. 2014. Pleistocene cave art from Sulawesi, Indonesia. Nature 514(7521):223-227. doi.org/10.1038/nature13422 (accessed 5 June 2018).

Aubert, M., S. O’Connor, M. McCulloch, G. Mortimer, A. Watchman and M. Richer-LaFlèche. 2007. Uranium-series dating rock art in East Timor. Journal of Archaeological Science 34(6):991-996. doi.org/ 10.1016/j.jas.2006.09.017 (accessed 5 June 2018).

Ballard, C. 1988. Dudumahan: A rock art site on Kai Kecil, SE Moluccas. Bulletin of The Indo-Pacific Prehistory Association 8:139-161. doi.org/10.7152/bippa.v8i0.11274 (accessed 5 June 2018).

BCPBM (Balai Pelestarian Cagar Budaya Makassar). 2015. Pendataan Cagar Budaya di Kabupaten Muna Provinsi Sulawesi Tenggara, Makassar.

Bellwood, P. 2017. First Islanders: Prehistory and Human Migration in Island Southeast Asia. Hoboken, NJ: John Wiley \& Sons. doi.org/10.1002/9781119251583 (accessed 5 June 2018).

Chazine, J.-M. 1999. Unraveling and reading the past in Borneo: An archaeological outline of Kalimantan. In J.-C. Galipaud and I. Lilley (eds), Le Pacifique de 5000 à 2000 avant le Présent : Suppléments à l'Histoire d'une Colonisation [The Pacific from 5000 to 2000 BP: Colonisation and Transformations]. Paris: Colloques et séminaires.

Chazine, J.-M. 2011. New survey of painted panels off North West Papua: A precise identification of their location parameters and some insight into their function, pp. 106-114. XXIV Valcamonica Symposium, June. Capo di Ponte, Italy: Centro Camunio di Prehistoria and Pr. Anati Emmanuel.

Fage, L.-H. 2015. Rapport préliminaire: Prospection archéologique, massif de Matarombeo Sulawesi Central, octobre 2014, NaturEvolution. doi.org/10.13140/RG.2.1.1934.3205 (accessed 5 June 2018).

Fage, L.-H., J.-M. Chazine and P. Setiawan. 2010. Borneo, Menyingkap Gua Prasejarah. Jakarta: Le Kalimanthrope.

Fauzi, M.R., S.E. Prasetyo, F.S. Intan, W. Andhifani and A.O. Hendrata. 2015. Survei Arkeologis Potensi Gua di Provinsi Jambi Tahap II. Laporan Penelitian Arkeologi. Palembang: Balai Arkeologi Palembang.

Galipaud, J.-C., R. Kinaston and D. Guillaud. 2016. Aleti Tunu Bibi: Contextualizing a new rock art site in East Timor and the wider Asia-Pacific region. Asian Perspectives 55(2):128-147. doi.org/10.1353/ asi.2016.0016 (accessed 5 June 2018).

Gonthier, E., Budiman, E.N.I. Djami and T. Simanjuntak. 2013. Art pariétal dan le baie de Triton, sud-ouest de la Papua-Barat: Études sémiologiques des tracés pariétaux archéologiques. Les Amis du Muséum National d'Histoire Naturelle 256:54-57.

Hall, K.R. 1992. Economic history of early Southeast Asia. In N. Tarling (ed.), The Cambridge History of Southeast Asia, pp. 183-275. Cambridge: Cambridge University Press.

Harman, J. 2008. Using decorrelation stretch to enhance rock art images. www.dstretch.com/Algorithm Description.html. (Paper originally presented American Rock Art Research Association Annual Meeting 2005.)

Joordens, J.C.A., F. d'Errico, F.P. Wesselingh, S. Munro, J. de Vos, J. Wallinga, C. Ankjaergaard, T. Reimann, J.R. Wijbrans, K.F. Kuiper, H.J. Mucher, H. Coqueugniot, V. Prie, I. Joosten, B. van Os, A.S. Schulp, M. Panuel, V. van der Haas, W. Lustenhouwer, J.J.G. Reijmer and W. Roebroeks. 2015. Homo erectus at Trinil on Java used shells for tool production and engraving. Nature 518(7538):228-231. doi.org/ 10.1038/nature13962 (accessed 5 June 2018). 
Kosasih, E.A. 1985. Hasil penelitian lukisan-lukisan pada beberapa gua dan ceruk di Pulau Muna (Sulawesi Tenggara). In R.P. Soejono, S. Suleiman, S. Satari, N.A. Subagus and R. Indraningsih (eds), Rapat Evaluasi Hasil Penelitian Arkeologi II, Cisarua, 5-10 Maret 1984, pp. 55-66. Jakarta: Pusat Penelitian Arkeologi Nasional.

Kosasih, E.A. 1987. Lukisan Gua Prasejarah: Bentangan Tema dan Wilayahnya. Diskusi Ilmiah Arkeologi II. Jakarta: Pusat Penelitian Arkeologi Nasional.

Kosasih, E.A. 1989. Sumbangan data seni lukis bagi perkembangan arkeologi di kawasan Asia Tenggara. Pertemuan Ilmiah Arkeologi V. Jakarta: Ikatan Ahli Arkeologi Indonesia.

Kosasih, E.A. 1995. Lukisan Gua di Sulawesi Bagian Selatan: Refleksi Kehidupan Masyarakat Pendukungnya. Unpublished PhD thesis, Department of Archaeology, University of Indonesia, Jakarta.

Lape, P.V., S. O'Connor and N. Burningham. 2007. Rock art: A potential source of information about past maritime technology in the south-east Asia-Pacific region. International Journal of Nautical Archaeology 36(2):238-253. doi.org/10.1111/j.1095-9270.2006.00135.x (accessed 5 June 2018).

Le Quellec, J.-L., F. Duquesnoy and C. Defrasne. 2015. Digital image enhancement with DStretch ${ }^{\circledR}$ : Is complexity always necessary for efficiency? Digital Applications in Archaeology and Cultural Heritage 2(2):55-67. doi.org/10.1016/j.daach.2015.01.003 (accessed 5 June 2018).

Marschall, W. and M. Wäfler. 2012. Felsmalereien Indonesiens. Band 1: Pulau Muna. Borsdorf: Edition Winterwork.

Maxwell, R.J. 1990. Textiles of Southeast Asia: Tradition, Trade, and Transformation. Oxford: Oxford University Press.

Maynard, L. 1977. Classification and terminology in Australian rock art. In P.J. Ucko (ed.), Form in Indigenous Art: Schematisation in the Art of Aboriginal Australia and Prehistoric Europe, pp. 387-403. Canberra: Australian Institute of Aboriginal and Torres Strait Islander Studies.

O'Connor, S. 2003. Nine new painted rock art sites from East Timor in the context of the Western Pacific region. Asian Perspectives 42(1):96-128. doi.org/10.1353/asi.2003.0028 (accessed 5 June 2018).

O’Connor, S., J. Louys, S. Kealy and Mahirta. 2015. First record of painted rock art in Kupang, West Timor, Indonesia and the origins and distribution of the Austronesian Painting Tradition. Rock Art Research 32(2):193-201.

O'Connor, S. and N.V. Oliveira. 2007. Inter-and intraregional variation in the Austronesian painting tradition: A view from East Timor. Asian Perspectives 46(2):389-403. doi.org/10.1353/asi.2007.0014 (accessed 5 June 2018).

Oktaviana, A.A. 2009. Penggambaran Motif Perahu pada Seni Cadas di Indonesia. Unpublished MA thesis, Program Studi Arkeologi, University of Indonesia, Jakarta.

Oktaviana, A.A. 2012. Teknik menggerakkan perahu yang terekam dalam seni cadas sebagai kekayaan seni dan maritim di Indonesia. In S. Rahardjo (ed.), Arkeologi untuk Publik, pp. 537-549. Jakarta: Ikatan Ahli Arkeologi Indonesia.

Oktaviana, A.A. 2015a. Kawasan Pula Muna, Sulawesi Tenggara. In R.C.E. Permana (ed.), Gambar Cadas Prasejarah di Indonesia, pp. 144-169. Jakarta: Direktorat Pelestarian Cagar Budaya dan Permuseuman.

Oktaviana, A.A. 2015b. Pengaplikasikan DStretch pada perekaman gambar cadas di Indonesia. In S.N. Titi and R. Handini (eds), Prosiding Diskusi Ilmiah Arkeologi (DIA) Tahun 2015 Perkembangan Penelitian Arkeologi Indonesia, pp. 72-90. Jakarta: Ikatan Ahli Arkeologi KOMDA Jabotabek. 
Oktaviana, A.A. 2016. Eksistensi gambar tangan negatif pada gambar cadas di Kawasan karst Pulau Muna, Sulawesi Tenggara. In H. Widianto (ed.), Jejak Austronesia di Indonesia, pp. 96-120. Yogyakarta: Gadjah Mada University Press.

Oktaviana, A.A., D. Bulbeck, S. O’Connor, B. Hakim, Suryatman, U.P. Wibowo, E. St Pierre and Fakhri. 2016. Hand stencils with and without narrowed fingers at two new rock art sites in Sulawesi, Indonesia. Rock Art Research 33(1):32-48.

Oktaviana, A.A., P. Lape and M.N. Ririmasse. 2016. Recent rock art research on East Seram, Maluku: $A$ key site in the rock art of West Papua and South East Maluku. 2nd SEAMEO SPAFA International Conference on Southeast Asian Archaeology, Bangkok, 30 May - 2 June.

Oktaviana, A.A., P. Setiawan and E.W. Saptomo. 2016. Rock art pattern in Harimau cave site in South Sumatra. In T. Simanjuntak (ed.), Harimau Cave and the long Journey of OKU Civilization, pp. 267-286. Yogyakarta: Gadjah Mada University Press.

Permana, R.C.E. 2005. Bentuk gambar telapak tangan pada gua-gua prasejarah di Kabupaten Pangkajene Kepulauan, Sulawesi Selatan. Wacana 7(2):161-174. doi.org/10.17510/wjhi.v7i2.304 (accessed 5 June 2018).

Plagnes, V., C. Causse, M. Fontugne, H. Valladas, J.-M. Chazine and L.-H. Fage. 2003. Cross dating (Th/U-14C) of calcite covering prehistoric paintings in Borneo. Quaternary Research 60(2):172-179. doi.org/10.1016/S0033-5894(03)00064-4 (accessed 5 June 2018).

Ririmasse, M.N. 2007. Tinjauan kembali seni cadas di Maluku. Kapata Arkeologi 3(4):1-21.

Setiawan, P. 1994. Gambar Cadas Dunwahan, Tinjauan awal Isi-Wimba Berdasarkan Posisi Sebenarnya di Cadas. Unpublished Graphic Arts thesis, Fakultas Seni Rupa dan Desain, Bandung Institute of Technology, Bandung.

Setiawan, P. 2004. Pesan dari jaman yang hilang: Gambar cadas Kalimantan. Seminar Penelitian Perancis di Indonesia, National Museum, Jakarta.

Setiawan, P. 2010. Gambar Cadas Kutai Prasejarah: Kajian Pemenuhan Kebutuhan Terpadu dan Komunikasi Rupa. Unpublished PhD thesis, Fakulta Seni Rupa dan Desain, Bandung Institute of Technology, Bandung.

Sulistyarto, P.H., A.A. Oktaviana, S. Adhityatama, A.S. Ramadhan, A.P. Ariadi, I. Mahmud and Y. Prameswari. 2014. Penelitian Arkeologi: Maritim Hunian Prasejarah dan Lukisan Cadas di Kepulauan Misool, Kabupaten Raja Ampit, Provinsi Papua Barat. Jakarta: Laporan Penelitian Arkeologi.

Suprapta, B. 1996. Lukisan Dinding Gua di Daerah Pangkep: Suatu Kajian tentang Makna Lukisan dalam Kehidupan Mesolitik. Unpublished MA thesis, Program Studi Arkeologi, University of Indonesia, Jakarta.

Szabó, K., P.J. Piper and G.W. Barker. 2009. Sailing between worlds: The symbolism of death in northwest Borneo. In G. Clark, F. Leach and S. O'Connor (eds), Islands of Enquiry: Colonisation, Seafaring and the Archaeology of Maritime Landscapes, pp. 149-170. Terra Australis 29. Canberra: ANU E Press.

Whitten, A.J., M. Mustafa and G.S. Henderson. 1987. The Ecology of Sulawesi. Yogyakarta: Gadjah Mada University Press.

Yondri, L. 1996. Batucap: Temuan awal tinggalan seni lukis gua/ceruk di wilayah Indonesia Barat. Jurnal Penelitian Balai Arkeologi Bandung 3:57-66. 
This text is taken from The Archaeology of Sulawesi: Current Research on the Pleistocene to the Historic Period, edited by Sue O'Connor, David Bulbeck and Juliet Meyer, published 2018 by ANU Press, The Australian National University, Canberra, Australia.

doi.org/10.22459/TA48.11.2018.06 